\title{
Household Strategies for Coping with the Financial Costs of HealthCare in Edo State, Nigeria DOI: 10.36108/NJSA/5102/13(0250)
}

\author{
Stanley A. Garuba ${ }^{1 *}$ \\ Bernard E. Owumi \\ ${ }^{1}$ Catholic Relief Services \\ Abuja, Nigeria \\ ${ }^{2}$ Department of Sociology \\ Faculty of the Social Sciences \\ University of Ibadan, Ibadan, Nigeria
}

Corresponding Author: stanleygaruba@yahoo.com

\begin{abstract}
The cross-sectional survey design was used in the study to elicit data in Edo State, Nigeria to assess the strategies employed by households to cope with the financial costs of healthcare. Questionnaire data were collected from 508 household respondents in three randomly-selected Local Government Areas of the state including Esan-west, Etsako-west and Egor. Twelve Focus Group Discussions complemented survey data. The main strategies to cope with the financial costs of health care were mobilization of cash and savings (40.5\%), and sale of produce and assets (16.0\%). Level of income was a significant factors affecting the ability to mobilize cash and savings to cope with the financial costs of health care $\left(X^{2}=31.787,4 d f, p<0.05\right.$, critical value $=9.49$ ). Diversion of money intended for food, education, and clothes to cope with the financial costs of health care was common, relatively, to respondents with low income level $\left(X^{2}=13.050,4 d f, p<0.05\right.$, critical value $\left.=9.94\right)$. The findings of the study indicate that urban households have the ability to cope with the financial costs of health care, than rural households. It is therefore imperative that government should not only make healthcare facilities available but should also alleviate poverty in society to enable people defray the cost of healthcare with minimal effort.
\end{abstract}

Keywords: financial costs, health care, coping strategies, household, Edo state

\section{Introduction}

Coping is a temporary mechanism employed within an existing system to forestall a harmful effect on household (Davis, 1993; Gore, 1992). For households of low socioeconomic status, ill health among members may be characterized by the inability to defray the cost of medical care on one hand and the limitation on the individual to engage in work during the illness period, on the other (Leathermen et al., 2012; O'Donnell et al., 2008; Leive and Xu, 2008; Xu et al., 2007; Xu et al., 2003; Wagstaff and Doorslaer, 2003). In different parts of countries, emphasis on issues related to illness is moving towards a more detailed understanding of the coping strategies with the costs of health care. Studies on coping strategies provide important information on 
the mechanisms employed to avert a negative effect of health shocks, and how payment for medical treatment may affect future welfare of the household (Leive and $\mathrm{Xu}, 2008$ ).

During health shocks, households may employ different strategies to cope with the costs of medical treatment (Sauerborn, Adams and Hien, 1996; Russell, 1996; Yu and Wilkes, 1998; Carrin, Gray and Almeida, 1998; Ding and Chen, 2001; Peters et al., 2001, Hai, Gao and Yao, 2004 and Liu, 2005; Bogale, Mariama and Ali, 2005). As the first coping strategies, households may decide to use savings, sell assets, borrow money from relatives, or secure a loan, especially when health costs is more than the household income. Where a major bread winner of a household is the one that is ill, other members of the household may begin to work to provide alternative income for the household and to repay loan (Leive and $\mathrm{Xu}, 2008$ ).

Several analytical frameworks have been used for understanding household coping strategies. One framework categorised coping strategies into production related adjustments, social adjustments, and biological strategies/body adaptations (Longhurst, 1986). Similarly, another framework classified coping strategies into eleven distinct types of strategies. Of those, seven relate to coping with the financial costs of illness, while four are for coping with the time costs of illness (Sauerborn, Adams and Hien, 1996). Besides, a Social Risk Management (SRM) matrix, which outlined three types of strategies that households employ to cope with adverse shocks was also proposed. The first type relate to prevention strategies, which is to reduce the likelihood that the household will experience the shock. The second sets of the strategies were termed mitigation strategy, which is to decrease the potential impact of a future shock, including portfolio diversification, insurance, hedging/risk exchange. The third categories were the coping strategies, which is to relieve the impact, once the shock has occurred (Holzmann and Jorgensen, 2000; Ding, Chen, Feng and $\mathrm{Li}, 2008$ ). The sequence of coping strategies also has been categorized into three typical production related adjustments, social adjustment, and expenditure adjustment (Longhurst, 1986; Goudge and Govender, 2000; Moser, 1998).

In general, coping strategies have been classified as ex ante and ex post strategies. Coping strategies for reducing the likelihood of illness incidence or decreasing the damaging impact of a potential illness were classified as ex ante coping strategies, while the coping strategies designed to relieve the actual impact of an illness, were classified as ex post strategies (Ding, Chen, Feng and $\mathrm{Li}$, 2008). In addition, ex post strategies were further classified into consumption adjustment strategies and production adjustment strategies $(\mathrm{Yu}$ and Wilkes, 1998), or financial adjustment strategies and time adjustment strategies (Jiang and Braun, 2005). Nevertheless, the various classifications of ex post coping strategies are similar. The coping strategies, which have been classified as consumption adjustment strategies, are similar to financial 
adjustment strategies, while the coping strategies, which have been classified as production adjustment strategies, are similar to time adjustment strategies.

Since different strategies are employed to cope with the costs of health care, there is no peculiar approach in any part of the country. The ability to prevent the loss of production and assets, due to illness differ and dependent on household size, composition, assets, type, duration of illness and on clustering of crisis, involving concurrent illnesses (Sauerborn, Adams and Hien, 1996). The social, economic and physical environment affect household's sources and modes of payment for health care (Garuba, 2008), and the effectiveness of strategies adopted to cope with the costs of health care (Ding, Chen, Feng and Li, 2008).

From literature investigations, the categories of strategies employed to cope with costs of health care in different parts of the country include use of cash and savings; sale of livestock; sale of other assets; change of productive activities; borrowing from friends and relatives; borrowing from moneylenders or loans, in-kind help from friends and relatives; delay in payment to private health care providers; exemption from medical fees or free care; support from children and gift; reimbursement from medical schemes; social relief; income diversification; and wage-labour (Sauerborn, Adams and Hien, 1996; Yu and Wilkes, 1998; Jiang and Braun, 2005).

Despite the fact that the strategies employed to cope with costs of health care varied in different parts of Nigeria, few studies have been conducted to assess the coping strategies with the costs of health care in Nigeria. One nationwide survey conducted in 2003, including representative samples of the households, reported that the coping strategies adopted by people to mitigate the impact of cost recovery differ along geographical zones. Nigeria is divided into six geographical zones: North-central, Northeast, Northwest, Southeast, South-south and Southwest. The survey report indicated that the people in the Northeast find it difficult to adopt any coping strategy, whereas, people in the Southwest have more ways of coping with cost recovery than other people (Onibukun, 2003). However, the nationwide assessment did not include any State-level analysis of the strategies employed to cope with the impact of cost recovery.

Health care is on the concurrent list in the Nigerian Constitution, which implies that each level of government (federal and state) has legislative authority on it. The federal and state governments both have roles to ensure health care for the citizens. The different States do not only differ in terms of access to resources, the attitudes of the governments to health services delivery are not also the same. In the 1980s, when the federal government of Nigeria introduced the policy of cost recovery for health service delivery, some state governments declared free health care services for their citizens, while some simply did not take any significant step to improve access to health care for the people. State-level assessment of the coping strategies with the financial costs of health care is therefore important in order to understand the extent that states are implementing the policy. 


\section{Theoretical and Conceptual Framework}

The Voluntary Social Action Theory by Talcott Parsons has been adopted as theoretical perspective for the study. The perspective emphasises the overriding nature of socio-cultural factors over individuals' perceptions, attitudes and behaviour (Nwokocha, 2007). Very much like Max Weber's social action theory, which asserts the primacy of society over the individual person (Giddens, 2000), it argues that societies exert social constraint over the actions of individuals. However, Parsons emphasised the importance of societal factors in constraining the ends that an individual can pursue and the means of pursuing them.

Five basic premises were posited by Parsons for the social action theory. These are:

1. People's actions are directed toward the achievement of end goals;

2. People adopt the appropriate means and procedure from those available to attain their ends;

3. Courses of action are determined by the conditions of the physical and social environment;

4. Individuals have emotions and make moral judgements, which influence the selection of ends and mean and their priority;

5. Actions are to be explained by the subjectively intended meaning given them by the actors, or roughly, by his/her perception and definition of the ends and conditions of his/her situation.

The key elements in the theory are action, end, actor and means. As the first basic premise states people's actions are directed toward the achievement of end goals, the course of health care financing is to achieve utilisation of health services by individuals. Funding for health care can be by different sources and modes of payment, but the ultimate goal is to afford health services which would help achieved an optimal state of health care by individuals. The utilisation of health services is a function of the sources and modes of payment. An individual may not be able to attain health care, due to lack of money and the financial costs of health services needed. He/she may borrow money to cope or take other measures, like he/she may decide not to seek after health care.

On the second premise of the social action theory, which states - people adopt the appropriate means and procedure from those available to attain their ends, it is to say that the sources and modes of payment for health care are based on available financing mechanisms to individuals. The available resources to an individual would affect his/her ability to afford health care. This is so because the affordability and utilisation of health services is determined by existing financing strategy. Figure 1 below illustrates a unilinear relationship of financing mechanism and health care utilisation. 


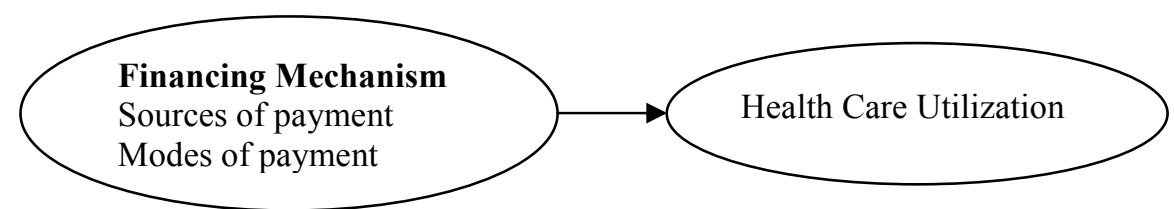

Figure 1: Relationship of Financing Mechanism and Health Care utilisation

The goal of health financing is to ensure accessibility of health care. Accessibility is, in part, determined by the affordability of health services for individuals and households. This depends on the effectiveness of available sources of funding and modes of payment. In Nigeria, data showed that the household is the major financing agent for health (HERFON, 2006), using personal income and sales of produce mainly on out-of-pocket payment basis to pay for health care (Soyibo, 2005). Therefore, the important question relates to knowing commonly used sources and modes of payment and how they affect health care utilisation in Edo State.

The third premise posited by Parsons holds that courses of action are determined by the conditions of the physical and social environment. The social and economic conditions determine the sources of funds used to buy health care and the commonly used modes of payment by individuals and households. This relationship is illustrated by Figure 2 below. It shows that the social and economic conditions collectively determine the financing mechanism adopted for health care by individuals.

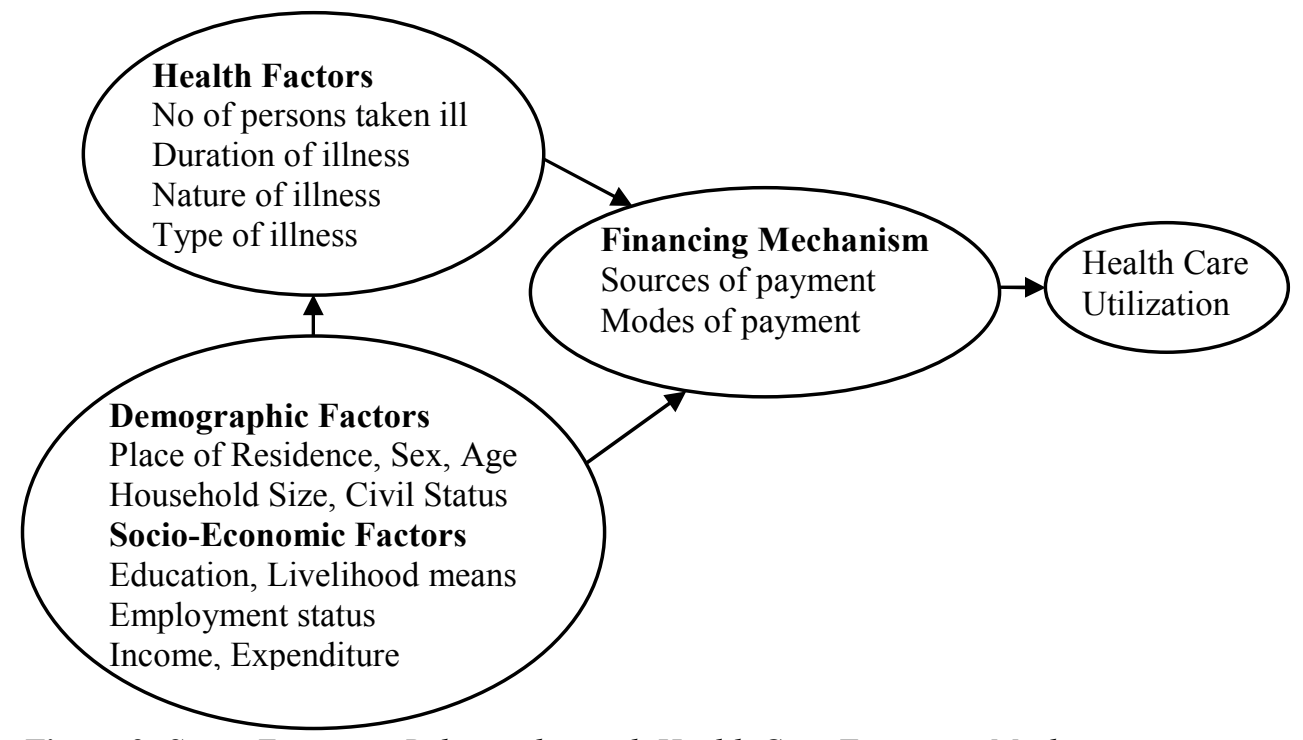

Figure 2: Socio-Economic Relationship with Health Care Financing Mechanism 
The fourth premise states that individuals have emotions and make moral judgements, which influence the selection of ends and means and their priority. The dynamics of health care financing affect the sources and modes of payment and utilisation of health care. An individual may be willing to pay for health care, but his/her ability to pay is subject to a number of factors, including the situation of illness experienced, the financial costs of health care and financing strategy. The willingness and ability to pay are affected by the available sources of funding and modes of payment for health care. Where an individual is willing and able to pay, cost considerations may not be a hindrance to his/her utilisation of health services. Figure 3 below illustrates the relationship of financing mechanism with willingness and ability to pay for health care.

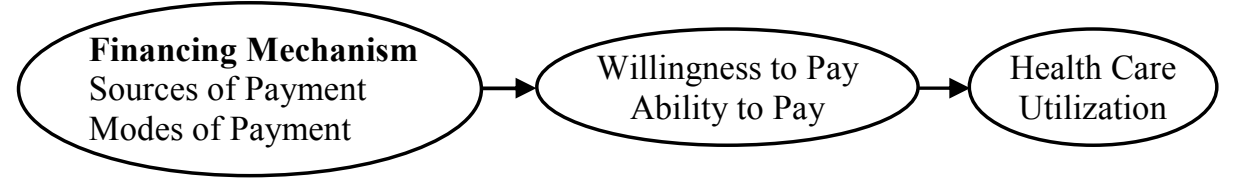

Figure 3: Financing Mechanism with Willingness and Ability to Pay

The fifth and final basic premise states that actions are to be explained by the subjectively intended meaning given them by the actors, or roughly, by his/her perception and definition of the ends and conditions of his/her situation. This means that the course of health care financing should be assessed with the affordability and utilisation of health services by individuals. This should be examined in relation to the social and economic conditions of the individuals, which often shape the financing mechanism to affect the utilisation of health care.

The assumptions of voluntary social action theory applied significantly to analysis of the relationship of the strategy of financing and utilisation of health services by individuals. It indicated that the course of health care financing may be determined by the social, economic and health situations of individuals and households. This affects the willingness and ability to pay for health care and utilisation. Willingness and ability to pay influence the attitudes to utilisation of health services. This relationship is represented schematically in Figure 4 showing the inter-relationships of the set of independent, intervening and dependent variables of the study. The major independent variable is health care financing mechanism, which was impinged by a set of antecedent variable of socio-economic, demographic and health factors. The intervening variables are willingness to pay (WTP) and ability to pay (ATP) for health care. The dependent variable is health care utilisation. 


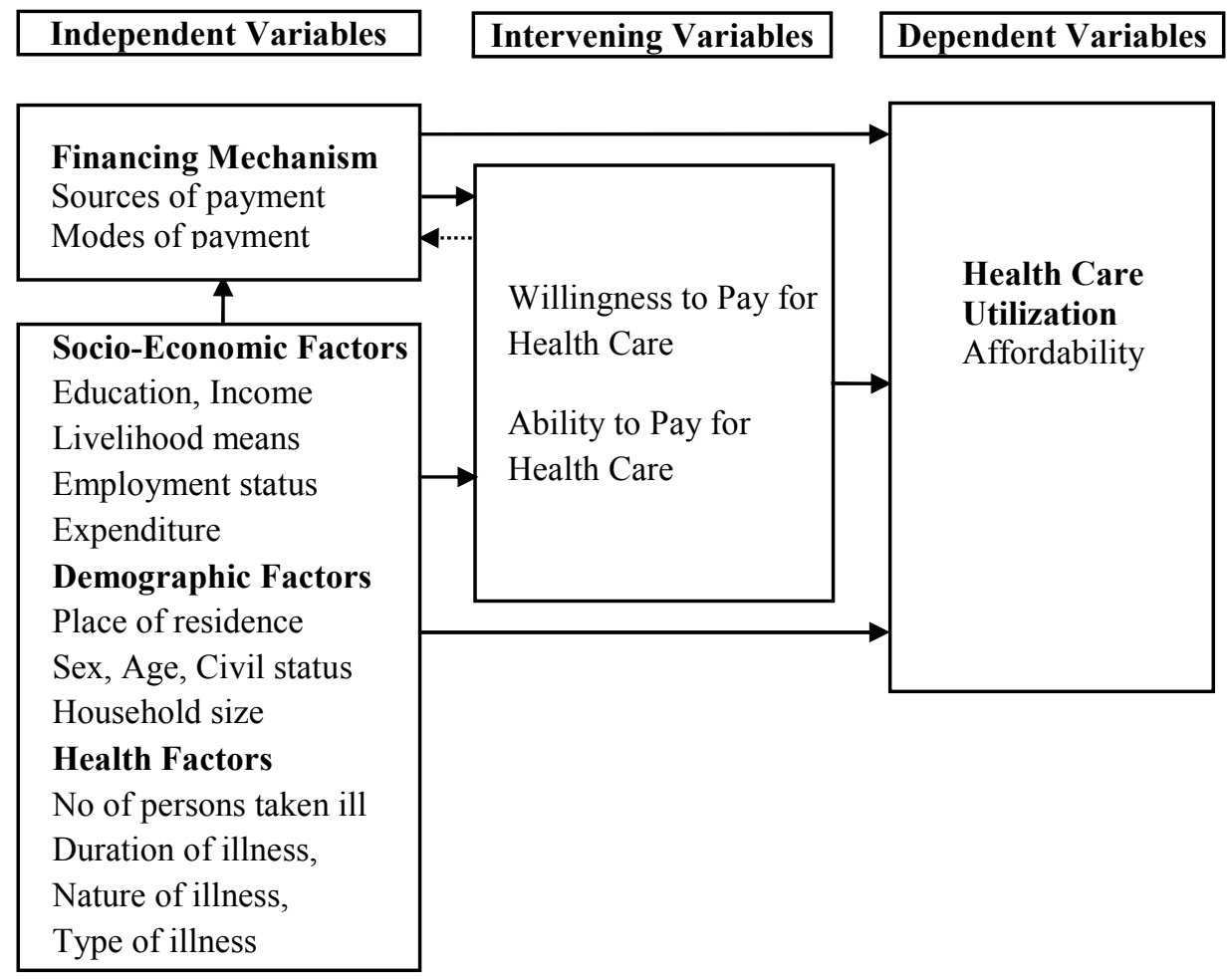

Figure 4: Conceptual Framework

Source: Authors, 2015

The sources of funding and methods used to pay for health care influenced the willingness and ability to pay, as well as the affordability of health care. The relationship of financing mechanism with the willingness and ability to pay may be dialectical. The social and economic conditions of individuals and households affect the willingness and ability to pay, as well as the utilisation of health services. The conceptual framework, therefore, suggested that the interplay of social and economic factors on financing mechanism with willingness and ability to pay, determined health care utilisation among the individuals and households.

\section{Materials and Methods}

\section{Brief Description of Edo State}

Edo State is one of the six states in the South-south geographical zone of Nigeria, with over three million population (Table 1). Edo State is endowed with abundant natural resources. The principal mineral resources include crude oil, natural gas, clay chalk, marbles and limestone. Agriculture is the predominant occupation of the people. This confirms why many of the people live in rural area. The major cash crops produced are rubber, cocoa and palm produce. In addition, there is production of such crops as yams, cassava; rice, 
plantains, guinea-corn, and assorted types of fruits and vegetables like citruses, pineapples, guava, coconut, mangoes, pear and cherry. The vast forest belt is rich in various species of economic trees. Also, it is in the forefront of palm oil and kernel production with three oil-processing mills. These companies provide a number of employments for skilled and semi-skilled workers. For their workers, they have provision for medical allowances or medical retainership contract with health care providers.

\section{Health Care System in Edo State}

The health care system in Edo operates in a three-tier form in line with the National Health Care System. The primary health care of the people is paramount at the local government levels while the state government takes charge of the Secondary Health Care and supervises Primary Health Care (PHC) at the local government level. Tertiary Health Care is mainly the responsibility of the federal government. Primary Health Care, the bedrock of the nation's health policy is expected to be given due attention at all levels of government. Although the implementation of PHC programmes is the responsibility of the local government councils (LGCs), the state enacts supervisory responsibilities to ensure proper coordination and execution of programmes through the provision of necessary logistics and other support to all LGCs. The State Government encourages the establishment of private health institutions to meet the growing demand for health care by the people. The management and coordination of the government-owned hospitals is through its Hospital Management Board (HMB) in Benin City (Garuba, 2008).

In Edo State, health insurance is lacking, consumers pay directly to access services from both the public and private health facilities. The practice of user fees became very dominant since the introduction of cost recovery (an approach whereby patients are expected to pay a token for services received) by the federal government in the 1980s. Fees for service are commonly collected by the private health service providers. The major private hospitals have registered with the National Health Insurance Scheme, but the coverage is still very low and limited to only Federal Government employees. The introduction of user fees did not lead to any significant improvement in accessibility of health care facilities in Nigeria. Rather, the introduction of user fees is blamed for the exclusion of the poor from accessing essential health services (Onibukun, 2003).

\section{Sampling and Sample Size}

A multi-stage sampling technique was used to select 508 household respondents in three randomly-selected Local Government Areas (LGAs) in Edo State. The selection of LGAs was based on the clusters of LGAs along the three major regions in Edo State. The LGAs selected include Esan west, in Edo Central; Etsako west, in Edo North; and Egor, in Edo South. Communities 
were purposively selected to ensure that one urban and one rural community was included in the study in all the three LGAs. The selected communities include Eguare, Emuado, Ayogwiri, Auchi, Uwasota and Uwelu. The systematic sampling technique was used to draw respondents from the communities

A structured, pre-tested questionnaire was used for collecting information on socio-demographic and economic status, health care expenditure and coping strategies with costs of health care. Trained interviewers who speak Pidgin English administered the questionnaire. The interviewers worked with the supervisor in all communities to ensure that the quality of data collected was guaranteed. The structured questionnaire was administered on 520 household representatives, but the investigators certified 508 for data analysis. Twelve completed questionnaire was rejected, either because there were too many missing or inconsistent forms, which was due mostly to interruptions that were beyond the control of the interviewers. Table 1 presents the distribution of study population in selected LGAs. We targeted 500 respondents, but, in the end, we analysed responses from 508.

\begin{tabular}{|c|c|c|c|c|c|c|c|}
\hline \multirow{2}{*}{ LGA } & \multirow{2}{*}{ Population } & \multirow{2}{*}{ Proportion } & \multirow{2}{*}{ Sample } & \multirow{2}{*}{ Rejection } & \multicolumn{3}{|c|}{ Respondents } \\
\hline & & & & & Urban & Rural & Total \\
\hline Egor & 339,889 & 51.15 & 266 & 6 & 130 & 130 & 260 \\
\hline $\begin{array}{l}\text { Esan } \\
\text { West }\end{array}$ & 125,842 & 19.04 & 99 & 2 & 48 & 48 & 94 \\
\hline $\begin{array}{l}\text { Etsako } \\
\text { West }\end{array}$ & 197,609 & 29.81 & 155 & 4 & 76 & 76 & 151 \\
\hline Total & 663,340 & 100 & 520 & 12 & 254 & 254 & 508 \\
\hline
\end{tabular}

Expenses during last illness experienced were used to estimate health care expenditure. The information on expenses during last illness included the costs of registration at the hospital, consultation, and admission in the hospital, laboratory examinations, purchase of drugs at the hospital and medicine store, cost of transportation that was as a result of illness, cost of feeding and accommodation at the hospital and any other non-classified payments. A household was regarded as a group of people who reside together, live on the same source of food and income. After pre-coding all the study variables, the raw data were entered into a computer using SPSS 10.0 for Windows software. Chi-square test was used for assessing the significance of the association between relevant variables. Statistical significance was set at $p<0.05$.

In addition, 12 Focus Group Discussions (FGDs) were conducted to elicit understanding on the nuance of the mechanisms adopted by the people to cope with the costs of health care. On the other hand, the FGDs to some extent provided additional explanation to support the analysis generated through the structured questionnaire. The focused discussions were conducted among 
heads of households, with homogenous members in terms of sex and community. In each community, two FGDs were conducted to ensure that male and female groups were equally represented in the survey. After collating the tape-recorded information and the detailed note taken during the FGDs, we analysed the information using ethnographic summaries and manual content analysis. Some important quotations from respondents during FGDs were reported verbatim to highlight common views on coping strategies with the costs of health care.

\section{Results}

Table 2 shows the socio-demographic characteristics of study population. Incidentally, half of the respondents were in rural and urban areas, respectively. Results show that female respondents were slightly more than the male respondents. Age of the respondents ranged from 25 years to 86 years, the mean $( \pm \mathrm{SD})$ and median age being $42.88( \pm 11.37)$ and 40 years respectively. The majority $(91.5 \%)$ were married at the time of the study. A large proportion (42.1\%) came from households made up of five to six persons. The educational attainment was predominantly secondary and primary school levels. About $32.0 \%$ were involved in farming and trading, as their primary means of livelihood, while $60.0 \%$ claimed to be in not-paid employment. The mean monthly total household income $( \pm$ SD) was $41,364( \pm 32,213)$ Naira, while the mean monthly total household consumption $( \pm$ SD) was $17,792( \pm 9,379)$ Naira. 
The Nigerian Journal of Sociology and Anthropology Vol. 13 no. 2

\begin{tabular}{|c|c|c|c|c|c|c|c|}
\hline \multirow{2}{*}{\multicolumn{2}{|c|}{ Characteristics }} & \multicolumn{2}{|c|}{ Rural $=254$} & \multicolumn{2}{|c|}{ Urban $=254$} & \multicolumn{2}{|c|}{ Total $=508^{*}$} \\
\hline & & \multirow{2}{*}{\begin{tabular}{r|} 
Count \\
134
\end{tabular}} & \multirow{2}{*}{$\begin{array}{r}\text { Percent } \\
52.8\end{array}$} & \multirow{2}{*}{$\begin{array}{r}\text { Count } \\
118\end{array}$} & \multirow{2}{*}{$\begin{array}{r}\text { Percent } \\
46.5\end{array}$} & \multirow{2}{*}{$\begin{array}{r}\text { Count } \\
252\end{array}$} & \multirow{2}{*}{$\begin{array}{c}\text { Perce } \\
\text { nt }\end{array}$} \\
\hline \multirow{3}{*}{$\begin{array}{l}\text { Sexpor } \\
\text { respondent }\end{array}$} & Male & & & & & & \\
\hline & Female & 120 & 47.2 & 136 & 53.5 & 256 & 50.4 \\
\hline & Total & 254 & 100.0 & 254 & 100.0 & 508 & 100.0 \\
\hline \multirow{6}{*}{$\begin{array}{l}\text { Age of } \\
\text { respondent }\end{array}$} & Under 25 years & 1 & 4.0 & 1 & 4.0 & 2 & 4.0 \\
\hline & $25-34$ years & 58 & 23.5 & 43 & 17.8 & 101 & 20.7 \\
\hline & $35-44$ years & 82 & 33.2 & 108 & 44.6 & 190 & 38.9 \\
\hline & $45-54$ years & 61 & 24.7 & 57 & 23.6 & 118 & 24.1 \\
\hline & Over 54 years & 45 & 18.2 & 33 & 13.6 & 78 & 16.0 \\
\hline & Total & 247 & 100.0 & 242 & 100.0 & 489 & 100.0 \\
\hline \multirow{5}{*}{$\begin{array}{l}\text { Marital } \\
\text { status }\end{array}$} & Married & 223 & 89.9 & 231 & 93.1 & 454 & 91.5 \\
\hline & Never married/single & 3 & 1.2 & 3 & 1.2 & 6 & 1.2 \\
\hline & Separated/divorced & 4 & 1.6 & 5 & 2.0 & 9 & 1.8 \\
\hline & Widowed & 18 & 7.3 & 9 & 3.6 & 27 & 5.4 \\
\hline & Total & 248 & 100.0 & 248 & 100.0 & 496 & 100.0 \\
\hline \multirow{6}{*}{$\begin{array}{l}\text { Household } \\
\text { size }\end{array}$} & $1-2$ persons & 18 & 7.2 & 19 & 7.7 & 37 & 7.4 \\
\hline & 3-4 persons & 65 & 25.9 & 82 & 33.1 & 147 & 29.5 \\
\hline & 5-6 persons & 109 & 43.4 & 101 & 40.7 & 210 & 42.1 \\
\hline & $7-8$ persons & 38 & 15.1 & 34 & 13.7 & 72 & 14.4 \\
\hline & Over 8 persons & 21 & 8.4 & 12 & 4.8 & 33 & 6.6 \\
\hline & Total & 251 & 100.0 & 248 & 100.0 & 499 & 100.0 \\
\hline \multirow{6}{*}{$\begin{array}{l}\text { Educational } \\
\text { attainment } \\
\text { of } \\
\text { respondent }\end{array}$} & No formal education & 41 & 16.1 & 12 & 4.8 & 53 & 10.5 \\
\hline & Primary & 84 & 33.1 & 52 & 20.6 & 136 & 26.9 \\
\hline & Secondary & 100 & 39.4 & 104 & 41.3 & 204 & 40.3 \\
\hline & Vocational & 9 & 3.5 & 18 & 7.5 & 28 & 5.5 \\
\hline & Tertiary & 20 & 7.9 & 65 & 25.8 & 85 & 16.8 \\
\hline & Total & 254 & 100.0 & 252 & 100.0 & 506 & 100.0 \\
\hline \multirow{8}{*}{$\begin{array}{l}\text { Livelihood } \\
\text { means of } \\
\text { respondent }\end{array}$} & Farming & 129 & 51.0 & 31 & 12.2 & 160 & 31.6 \\
\hline & Trading & 57 & 22.5 & 104 & 40.9 & 161 & 31.8 \\
\hline & Craftwork & 22 & 8.7 & 17 & 6.7 & 39 & 7.7 \\
\hline & Government work & 15 & 5.9 & 47 & 18.5 & 62 & 12.2 \\
\hline & Private company work & 18 & 7.1 & 51 & 20.1 & 69 & 13.6 \\
\hline & Labourers & 8 & 3.2 & & & 8 & 1.6 \\
\hline & Dependent & 4 & 1.6 & 4 & 1.6 & 8 & 1.6 \\
\hline & Total & 253 & 100.0 & 254 & 100.0 & 507 & 100.0 \\
\hline \multirow{4}{*}{$\begin{array}{l}\text { Employme } \\
\text { nt status of } \\
\text { respondent }\end{array}$} & Full-time employment & 59 & 23.9 & 122 & 50.2 & 181 & 36.9 \\
\hline & Part-time employment & 10 & 4.0 & 5 & 2.1 & 15 & 3.1 \\
\hline & Not in paid employment & 178 & 72.1 & 116 & 47.7 & 294 & 60.0 \\
\hline & Total & 247 & 100.0 & 243 & 100.0 & 490 & 100.0 \\
\hline \multirow{6}{*}{$\begin{array}{l}\text { Monthly } \\
\text { total } \\
\text { household } \\
\text { income }^{\ddagger}\end{array}$} & Under N20,001 (US \$ 154) & 80 & 31.5 & 21 & 8.3 & 101 & 19.9 \\
\hline & N20,001-N40,000 (US \$ 308) & 122 & 48.0 & 91 & 35.8 & 213 & 41.9 \\
\hline & N40,001-N60,000 (US \$ 462) & 38 & 15.0 & 71 & 28.0 & 109 & 21.5 \\
\hline & N60,001-N80,000 (US \$ 615) & 5 & 2.0 & 49 & 19.3 & 54 & 10.6 \\
\hline & Above N80,000 (US \$ 615) & 9 & 3.5 & 22 & 8.7 & 31 & 6.1 \\
\hline & Total & 254 & 100.0 & 254 & 100.0 & 508 & 100.0 \\
\hline \multirow{6}{*}{$\begin{array}{l}\text { Monthly } \\
\text { total } \\
\text { household } \\
\text { consumptio } \\
\mathrm{n}^{\ddagger}\end{array}$} & Under N20,001 (US \$ 154) & 191 & 75.2 & 172 & 67.7 & 363 & 71.5 \\
\hline & N20,001-N40,000 (US \$ 308) & 62 & 24.4 & 75 & 29.5 & 137 & 27.0 \\
\hline & N40,001-N60,000 (US \$ 462) & 1 & 0.4 & 3 & 1.2 & 4 & 0.8 \\
\hline & N60,001-N80,000 (US \$ 615) & & & 1 & 0.4 & 1 & 0.2 \\
\hline & Above N80,000 (US \$ 615) & & & 3 & 1.2 & 3 & 0.6 \\
\hline & Total & 254 & 100.0 & 254 & 100.0 & 508 & 100.0 \\
\hline & & & ing val & & resul & & \\
\hline
\end{tabular}


Complete information on expenditure during last illness was obtained from 444 respondents. The average total household expenditure was 2,576.23 ( \pm 4,330.22) Naira ranging from 0 to 58,500 Naira. Health care expenditure accounted for an average of about $15.5 \%$ of monthly total household expenditure, and about $8.0 \%$ of monthly total household income. In general, monthly household expenditure accounted for an average of $59.0 \%$ of the total monthly household income. Level of health care expenditure was relatively lower among the respondents in rural area compared to the respondents in urban area.

\begin{tabular}{|c|c|c|c|c|c|}
\hline \multirow{2}{*}{$\begin{array}{l}\text { Level of } \\
\text { expenditure* }\end{array}$} & \multirow{2}{*}{$\begin{array}{l}\text { Poportion of } \\
\text { household } \\
\text { expenditure }\end{array}$} & \multirow{2}{*}{$\begin{array}{l}\text { Poportion of } \\
\text { household } \\
\text { income }\end{array}$} & \multicolumn{3}{|c|}{ Place of residence ${ }^{\dagger}$} \\
\hline & & & Rural & Urban & Total \\
\hline Under $\$ 1,001$ & $5.6 \%$ & $2.4 \%$ & $\begin{array}{r}70 \\
31.1 \%\end{array}$ & $\begin{array}{r}60 \\
27.4 \%\end{array}$ & $\begin{array}{r}130 \\
29.3 \%\end{array}$ \\
\hline$¥ 1,001-\$ 2,000$ & $11.2 \%$ & $4.8 \%$ & $\begin{array}{r}76 \\
33.8 \%\end{array}$ & $\begin{array}{r}49 \\
22.4 \%\end{array}$ & $\begin{array}{r}125 \\
28.2 \%\end{array}$ \\
\hline$\$ 2,001-\$ 3,000$ & $16.9 \%$ & $7.3 \%$ & $\begin{array}{r}41 \\
18.2 \%\end{array}$ & $\begin{array}{r}54 \\
24.7 \%\end{array}$ & $\begin{array}{r}95 \\
21.4 \%\end{array}$ \\
\hline$\$ 3,001-\$ 4,000$ & $22.5 \%$ & $9.7 \%$ & $\begin{array}{r}22 \\
9.8 \%\end{array}$ & $\begin{array}{r}21 \\
9.6 \%\end{array}$ & $\begin{array}{r}43 \\
9.7 \%\end{array}$ \\
\hline Above $\$ 4,000$ & $\begin{array}{l}\text { Above } \\
22.5 \%\end{array}$ & Above $9.7 \%$ & $\begin{array}{r}16 \\
7.1 \%\end{array}$ & $\begin{array}{r}35 \\
16.0 \%\end{array}$ & $\begin{array}{r}51 \\
11.5 \%\end{array}$ \\
\hline Total & & & $\begin{array}{r}225 \\
100.0 \%\end{array}$ & $\begin{array}{r}219 \\
100.0 \%\end{array}$ & $\begin{array}{r}444 \\
100.0 \%\end{array}$ \\
\hline \multicolumn{6}{|c|}{$\begin{array}{l}{ }^{*} \text { Based on } 444 \text { respondents with non-missing expenditure. Some values were missing } \\
\text { because either recall was difficult or the respondents reported not making any medical } \\
\text { expenses, due to fatalistic belief in the divine healing power of God. Mean }( \pm S D)=2,576 \\
(4,330) \text { Naira } X^{2}=15.404,4 d f, p=.004 \text { (2-tailed), critical value }=9.49 \text {. }\end{array}$} \\
\hline
\end{tabular}

Table 4 shows the chi-square analyses of coping strategies with financial costs of health care with place of residence. The most commonly-mentioned strategies for coping with the financial costs of health care were mobilization of cash and savings, sale of produce and assets. Here we used produce to refer to farm products such as tubers, grains and economic crops, which are kept sometimes by households, until when there is a high demand and good prices to sell the products. In-kind payment (exchange of crops/services) to cope with the financial cost of health care was mentioned by some respondents $(3.4 \%)$ in the study. 


\begin{tabular}{|c|c|c|c|c|c|}
\hline \multirow{2}{*}{ Strategies* } & \multicolumn{2}{|c|}{ Place of residence } & \multirow{2}{*}{ Total } & \multicolumn{2}{|c|}{ Test $^{\dagger}$} \\
\hline & Rural & Urban & & $\mathrm{X}^{2}$ & $\mathrm{P}$ \\
\hline Mobilization of cash and savings & $\begin{array}{r}71 \\
28.2 \%\end{array}$ & $\begin{array}{r}134 \\
52.8 \%\end{array}$ & $\begin{array}{r}205 \\
40.5 \%\end{array}$ & 31.716 & .000 \\
\hline Sale of produce and assets & $\begin{array}{r}58 \\
23.0 \%\end{array}$ & $\begin{array}{r}23 \\
9.1 \%\end{array}$ & $\begin{array}{r}81 \\
16.0 \%\end{array}$ & 18.337 & .000 \\
\hline Exchange of produce for treatment & $\begin{array}{r}14 \\
5.6 \%\end{array}$ & $\begin{array}{r}3 \\
1.2 \%\end{array}$ & $\begin{array}{r}17 \\
3.4 \%\end{array}$ & 7.405 & .006 \\
\hline $\begin{array}{l}\text { Gift or handouts from children or } \\
\text { friends }\end{array}$ & $\begin{array}{r}5 \\
2.0 \%\end{array}$ & $\begin{array}{r}1 \\
0.4 \%\end{array}$ & $\begin{array}{r}6 \\
1.2 \%\end{array}$ & 2.731 & .098 \\
\hline $\begin{array}{l}\text { Diversion of money intended for } \\
\text { food, education, and clothes }\end{array}$ & $\begin{array}{r}16 \\
6.3 \%\end{array}$ & $\begin{array}{r}25 \\
9.8 \%\end{array}$ & $\begin{array}{r}41 \\
8.1 \%\end{array}$ & 2.073 & .150 \\
\hline $\begin{array}{l}\text { Diversion of money intended for } \\
\text { business }\end{array}$ & $\begin{array}{r}16 \\
6.3 \%\end{array}$ & $\begin{array}{r}11 \\
4.3 \%\end{array}$ & $\begin{array}{r}27 \\
5.3 \%\end{array}$ & 1.020 & .312 \\
\hline Borrowing & $\begin{array}{r}12 \\
4.8 \%\end{array}$ & $\begin{array}{r}8 \\
3.1 \%\end{array}$ & $\begin{array}{r}20 \\
4.0 \%\end{array}$ & 0.866 & .352 \\
\hline Use of all incomes of household & $\begin{array}{r}87 \\
34.5 \%\end{array}$ & $\begin{array}{r}83 \\
32.7 \%\end{array}$ & $\begin{array}{r}170 \\
33.6 \%\end{array}$ & 0.666 & .365 \\
\hline Free health care & $\begin{array}{r}2 \\
0.8 \%\end{array}$ & $\begin{array}{r}2 \\
0.8 \%\end{array}$ & $\begin{array}{r}4 \\
0.8 \%\end{array}$ & 0.000 & .997 \\
\hline National health insurance scheme & - & $\begin{array}{r}1 \\
0.4 \% \\
\end{array}$ & $\begin{array}{r}1 \\
0.2 \% \\
\end{array}$ & 0.994 & .319 \\
\hline $\begin{array}{l}{ }^{*} \text { Information on coping strategies } \\
\text { on how respondents were coping } \\
\text { vital information, based on the tic } \\
\text { respondents. Hence, complete infor } \\
\text { subsets of the population of studies. }\end{array}$ & $\begin{array}{l}\text { btainec } \\
\text { the cos } \\
\text { or } \mathrm{m} \\
\text { on was } \\
0.05(2\end{array}$ & $\begin{array}{l}\text { ed on } m \\
\text { health } \\
n \text { of an } \\
\text { ined on } \\
\text { ed }), 1 d\end{array}$ & $\begin{array}{l}\text { tiple an } \\
\text { are. We } \\
\text { of the }\end{array}$ & $\begin{array}{l}\text { vers to } \\
\text { eport } 1 \\
\text { ping }\end{array}$ & $\begin{array}{l}\text { stion } \\
\text { y the } \\
\text { es by } \\
\text { from }\end{array}$ \\
\hline
\end{tabular}

In addition, the majority of the participants in the FGDs mentioned the diversion of the money, which was intended for food, education and clothes to cope with the financial costs of health care. Another strategy, which was generally mentioned for coping with the financial costs of health care, is borrowing. An excerpt from one of the FGD sessions indicates as follows: Illness is not a welcome condition of the household. This is because illness often creates financial difficulties and instability in the economy of the household. In such circumstance, you can divert the money that was intended for education to buy drugs or pay for treatments. As a result, children may stop going to school, because the school fees were not paid. Members of the household suffer lack of access to basic necessities, because a major source of household income might have stopped functioning, due to illness. This may cause panics in the household. If the situation deteriorates, one can borrow from other relatives, friends, community associations or moneylenders to cope with the costs of illness. After borrowing, the family start to bear the burden of repaying loan. In all, the family is subjected 
to more hardships. Property/assets would be sold to cope with the costs of illness, and it will be difficult to meet the basic needs of members of the family. Health care expenditures are sudden expenses, which have to be made by the family. (Male FGD/ Uwasota/Benin City: June 2006)

Furthermore, the reports of the FGDs show that borrowing is a common coping strategy with the financial costs of healthcare, especially where the use of other strategies have been exhausted. Borrowing can be from friends, neighbours or appeals to patent medicine vendors/pharmacy shops to give drugs/treatment, and allow payment to be made at a later date. The terms of borrowing from moneylenders have more serious implications on household economy. The conditions could really be very harsh. See additional excerpts from the report of the FGDs below.

When medical bills become very difficult to pay one has to borrow. You can borrow from moneylenders, with the intention to repay the loan by instalment. If you go to herbalist for treatment, you might be asked to provide a chicken or goat, as a form of payment for treatment of your ailment. It depends on the herbalist choice of the forms of payment for treating ailments. (Female FGD/Ayogwiri/Etsako West LGA: July 2006)

The cost of health care is usually too much, since one does not have all the money to pay, borrowing become very necessary. But the impact of repaying the money which was borrowed with interest can indeed be very hard on the household. (Male FGD/Auchi/Etsako West LGA: July 2006)

If you default in loan repayment, additional interest is calculated on the whole sum by the creditor. Sometimes, the only option available is to sell some important assets, like furniture and livestock (if you have them) to repay the loan. (Male FGD/Auchi /Etsako West LGA: July 2006)

In Table 5, results indicate that respondents in urban area, commonly mentioned mobilization of cash and savings to cope with the financial costs of health care. The majority $(52.8 \%)$ of the respondents in urban area mentioned the mobilization of cash and savings compared to $28.2 \%$ of the respondents in rural area who mentioned same for coping with the financial costs of health care. Twenty-three percent of the respondents in rural area mentioned the sale of produce and assets, while $9.1 \%$ of the respondents in urban area mentioned same for coping with the financial costs of health care. In-kind payment 
(exchange of crops/services) was commonly-mentioned by $5.6 \%$ of the respondents in rural area.

Table 5 shows that households with relatively higher income level have the ability to mobilize cash and savings to cope with the financial costs of health care than households with lower income level. The results showed that households with relatively lower income level mostly mentioned diversion of money that was intended for food, education and clothes to cope with the financial costs of health care.

\begin{tabular}{|c|c|c|c|c|c|c|c|c|c|}
\hline \multirow[b]{2}{*}{ Strategies ${ }^{*}$} & \multirow[b]{2}{*}{$\begin{array}{c}\text { Under } \\
\text { N20,001 } \\
\text { (US\$154) }\end{array}$} & \multirow[b]{2}{*}{$\begin{array}{l}\$ 20,001- \\
\$ 40,000 \\
\text { (US\$308) }\end{array}$} & \multicolumn{4}{|c|}{ Monthly total households income ${ }^{\dagger}$} & \multicolumn{3}{|c|}{ Test ${ }^{\frac{t}{4}}$} \\
\hline & & & $\begin{array}{l}\$ 40,00- \\
N 60,000 \\
\text { (US\$462) }\end{array}$ & $\begin{array}{l}N 60,001- \\
N 80,000 \\
\text { (US\$615) }\end{array}$ & $\begin{array}{c}\text { Above } \\
N 80,000 \\
\text { (US\$615) }\end{array}$ & Total & $\mathrm{X}^{2}$ & $\mathrm{df}$ & $P$ \\
\hline $\begin{array}{l}\text { Mobilization of cash } \\
\text { and savings }\end{array}$ & $\begin{array}{r}24 \\
24.2 \%\end{array}$ & $\begin{array}{r}76 \\
35.7 \%\end{array}$ & $\begin{array}{r}56 \\
51.4 \%\end{array}$ & $\begin{array}{r}35 \\
64.8 \%\end{array}$ & $\begin{array}{r}14 \\
45.2 \%\end{array}$ & $\begin{array}{r}205 \\
40.5 \%\end{array}$ & 31.787 & 4 & .000 \\
\hline $\begin{array}{l}\text { Diversion of money } \\
\text { intended for food, } \\
\text { education, and } \\
\text { clothes }\end{array}$ & $\begin{array}{r}3 \\
3 . .0 \%\end{array}$ & $\begin{array}{r}15 \\
7.0 \%\end{array}$ & $\begin{array}{r}17 \\
15.6 \%\end{array}$ & $\begin{array}{r}5 \\
9.3 \%\end{array}$ & $\begin{array}{r}1 \\
3.2 \%\end{array}$ & $\begin{array}{r}41 \\
8.1 \%\end{array}$ & 13.050 & 4 & .011 \\
\hline $\begin{array}{l}\text { Use of all incomes } \\
\text { of household }\end{array}$ & $\begin{array}{r}39 \\
39.4 \%\end{array}$ & $\begin{array}{r}74 \\
34.7 \%\end{array}$ & $\begin{array}{r}37 \\
33.9 \%\end{array}$ & $\begin{array}{r}13 \\
24.1 \%\end{array}$ & $\begin{array}{r}7 \\
22.6 \%\end{array}$ & $\begin{array}{r}170 \\
33.6 \%\end{array}$ & 5.504 & 4 & .239 \\
\hline $\begin{array}{l}\text { Sale of produce and } \\
\text { assets }\end{array}$ & $\begin{array}{r}17 \\
17.2 \%\end{array}$ & $\begin{array}{r}40 \\
18.8 \%\end{array}$ & $\begin{array}{r}17 \\
15.6 \%\end{array}$ & $\begin{array}{r}3 \\
5.6 \%\end{array}$ & $\begin{array}{r}4 \\
12.9 \%\end{array}$ & $\begin{array}{r}81 \\
16.0 \%\end{array}$ & 5.940 & 4 & .204 \\
\hline $\begin{array}{l}\text { Exchange of } \\
\text { produce for } \\
\text { treatment }\end{array}$ & $\begin{array}{r}4 \\
4.0 \%\end{array}$ & $\begin{array}{r}9 \\
4.2 \%\end{array}$ & $\begin{array}{r}2 \\
1.8 \%\end{array}$ & $\begin{array}{r}1 \\
1.9 \%\end{array}$ & $\begin{array}{r}1 \\
3.2 \%\end{array}$ & $\begin{array}{r}17 \\
3.4 \%\end{array}$ & 1.793 & 4 & .774 \\
\hline $\begin{array}{l}\text { Diversion of money } \\
\text { intended for } \\
\text { business }\end{array}$ & $\begin{array}{r}7 \\
7.1 \%\end{array}$ & $\begin{array}{r}8 \\
3,8 \%\end{array}$ & $\begin{array}{r}10 \\
9.2 \%\end{array}$ & $\begin{array}{r}2 \\
3.7 \%\end{array}$ & -- & $\begin{array}{r}27 \\
5.3 \%\end{array}$ & 6.854 & 4 & .144 \\
\hline $\begin{array}{l}\text { Gifts/or handouts } \\
\text { from children or } \\
\text { friends }\end{array}$ & $\begin{array}{r}3 \\
3.0 \%\end{array}$ & $\begin{array}{r}3 \\
1.4 \%\end{array}$ & -- & -- & -- & $\begin{array}{r}6 \\
1.2 \%\end{array}$ & 5.293 & 4 & .259 \\
\hline Borrowing/loans & $\begin{array}{r}3 \\
3.0 \%\end{array}$ & $\begin{array}{r}10 \\
4.7 \%\end{array}$ & $\begin{array}{r}7 \\
6.4 \%\end{array}$ & -- & -- & $\begin{array}{r}20 \\
4.0 \%\end{array}$ & 5.780 & 4 & .216 \\
\hline Free care & $\begin{array}{r}1 \\
1.0 \%\end{array}$ & $\begin{array}{r}1 \\
0.5 \%\end{array}$ & -- & -- & $\begin{array}{r}2 \\
6.5 \%\end{array}$ & $\begin{array}{r}4 \\
0.8 \%\end{array}$ & 14.284 & 4 & .006 \\
\hline $\begin{array}{l}\text { National health } \\
\text { insurance scheme }\end{array}$ & $\begin{array}{r}1 \\
1.0 \%\end{array}$ & -- & -- & -- & -- & $\begin{array}{r}1 \\
0.2 \%\end{array}$ & 4.119 & 4 & .390 \\
\hline $\begin{array}{l}{ }^{*} \text { Information on } \\
\text { respondents were } \\
\text { the ticking or ment } \\
\text { obtained on the eacl }\end{array}$ & $\begin{array}{l}\text { strategi } \\
\text { with th } \\
\text { of any of } \\
\text { ing strat }\end{array}$ & $\begin{array}{l}\text { was o } \\
\text { sts of } \\
\text { e copir } \\
\text { from }\end{array}$ & $\begin{array}{l}\text { ned b } \\
\text { th car } \\
\text { rategi }\end{array}$ & $\begin{array}{l}\text { on } \mathrm{m} \\
\text { repor } \\
\text { respo }\end{array}$ & $\begin{array}{l}\text { le answ } \\
\text { e only tl } \\
\text { tts. Hen }\end{array}$ & $\begin{array}{l}\text { to } \\
\text { vita } \\
\text { con }\end{array}$ & ques & & $\begin{array}{l}\text { how } \\
\text { d on } \\
\text { was }\end{array}$ \\
\hline
\end{tabular}

\section{Discussion}

In this study, expenditure on healthcare accounted for a high proportion of household income. The average total proportion $(8.0 \%)$ of household income was close to the finding of a study which showed that if other associated costs, such as transportation costs were added, the total direct costs of health services can be as high as $10.0 \%$ of household income (Lucas and Nuwagaba, 1999). Similarly, health care expenditure accounted for a high proportion of total 
consumption expenditure, and some respondents were seen to spend above the average total expenditure on health care. This finding supports an earlier national report, which indicated that many households spend high proportion of their consumption expenditure on health care (Federal Republic of Nigeria, 2006).

In this study, mobilization of cash and savings was employed by a significant proportion $(40.5 \%)$ of the respondents to cope with the financial costs of health care. In general, borrowing, sale of produce and assets were the second most commonly-mentioned mechanisms employed to cope with the financial costs of health care. The findings of this study compare well with earlier studies, where sale of assets (such as livestock, furniture, and stored grains), use of savings and borrowing were found to be the main strategies employed to cope with the costs of health care (Taiwo and Owumi, 2014; Sauerborn, Adams and Hien, 1996; Onibukun, 2003; Swift, 1989; Adams, 1992; Adams, 1993; Reardon, Malton and Delgado, 1988). Besides, the finding of another similar study has showed that most households employ strategies such as consuming less of other basic necessities, sale of assets and borrowing to cope with expenditures (McIntyre, 2005).

In addition, some respondents diverted the money that was intended for food, education and clothes to cope with the financial costs of health care. Similar results have been reported in Ethiopia, where households used the cash, which was intended for basic consumption need including food, fuel, clothes and education, to cope with the financial costs of health care (Russell and Abdella, 2002).

The finding of this study indicated that place of residence has a significant influence on the ability to cope with the financial costs of health care. Households in the rural area were seen to find it more difficult to cope with the financial costs of health care compared to households in the urban area. While $52.8 \%$ of the respondents in urban area adopted the mobilization of cash and savings to cope with the financial costs of health care, $23.0 \%$ of the respondents in rural area adopted sale of produce and assets to cope with the financial costs of health care. This finding is similar to the results which were reported in an earlier study, where rural households mainly either seek for waiver from facilities or sell assets to cope with health care expenditure (Bogale, Mariama and Ali, 2005).

\section{Conclusion}

The study has provided in-depth information on the coping strategies with the financial costs of health care in Edo. The level of expenditures on health care was relatively high. Health care expenditure was significantly associated with place of residence, which indicated, therefore, the ability to cope with the financial costs of health care. Households in urban area have the ability to cope with the financial costs of health care, than households in rural area. Level of 
income was a significant factor in coping with the financial costs of health care. Mobilization of cash and savings, borrowing, sale of produce and assets were the strategies, said to be commonly adopted for coping with the financial costs of health care.

There is a need for the state government to fast track the introduction of a social health insurance to cover the people in Edo, similar to the federal government's introduction of the National Health Insurance Scheme to cover the federal workers. There is a need to increase access to market for the people in the rural areas to sell their farm produce, in order to increase their income and the ability to cope with the financial costs of health care.

\section{References}

Adams, A.M. (1993) Food insecurity in Mali: exploring the role of moral economy. IDS Bull, 24, 41.

Adams, A.M. (1992) Seasonal food insecurity in the Sahel: nutritional, social and economic risk among Bamana agriculturalists in Mali. London: University of London, $\mathrm{PhD}$. Thesis.

Bogale, T.; Mariama, D.H.; Ali, A. (2005) Costs of illness and coping strategies in a coffee growing rural district of Ethiopia. $J$ Health, Popul Nutr, 23: 192-199.

Carrin, G.; Gray, E.; Almeida, J. (1998) Coping with ill-health in a rickshaw puller's household in Chittagong, Bangladesh. Geneva: Division of Intensified Cooperation with Countries in Greatest Need, World Health Organization. (Macroeconomics, health, and development series no. 30; Technical paper) (WHO/ICO/MESD-30).

Chen, J.L.; Ge, M.C. (2005) A study on the epidemiological survey of tuberculosis in rural areas in Xianning City. Chinese Rural Health Service Admin, Chinese, 25: 30.

Davies, S. (1993) Are coping strategies a cop out? IDS Bull, 24: 60-79.

Ding, S.; Chen, Y.; Feng, L.; Li, Z. (2008) Prevalence of illness and household ill-health risk coping strategies in rural China: a Chinese literature review. Studies in HSO\&P, 23:55-81. Retrieved on April 9, 2009, from http:// www. itg.be/itg/Uploads/Volksg ezondheid/povill/.

Ding, S.J.; Chen, C.B. (2001) Analysis of farm households' risk coping mechanisms. Res Agric Modern, In Chinese, 22: 346-349.

Federal Republic of Nigeria (2006) National health financing policy.

Garuba, S.A. (2008) Financing mechanism and sustainability of health care utilisation in Edo State Nigeria. Ibadan, $\mathrm{PhD}$, Thesis. University of Ibadan.

Gore, C. (1992) Entitlement relations and unruly social politics: a comment on the work on Amarrtya Sen. mimeo IDS, Brighton. In Sauerborn A., Adams A., Hien M. (eds.). Household strategies to cope with the economic costs of illness. Soc Sc Med, 43: 291-301.

Goudge, J.; Govender, V. (2000) A review of experience concerning household ability to cope with the resource demands of ill health and health care 
utilisation. Harare: Training and Resource Centre, Regional Network for Equity in Health in Southern Africa (EQUINET), Policy series no. 3.

Hai, W.; Gao, M.T.; Yao, Y. (2004) The impact of serious illness on Chinese rural households. Soc Security Sys, Chinese, 4: 43-45.

Holzmann, R.; Jorgensen, S. (2000) Social risk management: the new conceptual framework for social protection, and beyond. Social Protection Discussion Paper, 0006. The World Bank.

Jiang, Y.S.; Braun, J. (2005) The economic cost of illness and household coping strategies in western rural China. Chinese Rural Economy, Chinese, 11: 33-39.

Leatherman, S.; Geissler, K.; Gray, B.; Gash, M. (2012) "Health Financing: A new role for Microfinance Institutions". Freedom from Hunger Research Paper No. 16. http://onlinelibrary.wiley.com/doi/10.1002/jid.2829.abstract.

Leive, A.; Xu, K. (2008) Coping with out-of-pocket health payments: empirical evidence from 15 African countries. Bull World Health Organ, 86: 817-908.

Liu, Z.X. (2005) The farmers' health-seeking behaviour features; Health Econs Res, Chinese, 3: 36.

Longhurst, R. (1986) Household food strategies in response in seasonality and famine. IDS Bull, 17: 27-35.

Lucas, H.; Nuwagaba, A. (1999) Household coping strategies in response to the introduction of user charges for social service: a case study on health in Uganda. Brighton. (IDS Working paper no. 86).

Makinen M.; Waters, H.; Rauch, M.; Almagambetova, N.; Bitran, R.; Gilson L. et al. (2000) Inequalities in health care use and expenditures: empirical data from eight developing countries and countries in transition. Bull World Health Organ, 78: 55-65.

Mbugua, J.K. (1993). Impact of user charges on health care utilisation patterns in rural Kenya: the case of Kibwezi Division. Brighton: University of Sussex.

McIntyre, D.; Gilson, L. (2005) Equitable health care financing and poverty challenges in the African context, South Africa: Regional Network for Equity in Health in Southern Africa (EQUINET). Paper presented to forum 9, Global forum for health research, Mumbai, September). Retrieved on April 9, 2009, from http://www.who.int/nha.

McIntyre. D.; Thiede, M.; Mutyambizi, V.; Mekonnen, A. (2005) The never ending cycle of poverty and illness: can it be broken? Coping with the cost of illness in Debresina Woreda, Ethiopia. London: Save the Children.

McPake, B.; Hanson, K.; Mills, A. (1993) Community financing of health care in Africa: an evaluation of the Bamako Initiative. Soc Sc Med, 36: 13831395.

Moser, C. (1998) The asset vulnerability framework: reassessing urban poverty reduction strategies. World Development, 26: 1-19. 
Nwokocha, E.E. (2007) "Maternal Crises and the Role of African Men: the case of a Nigerian Community". African Population Studies, 22(1): 39-62.

O’Donnell, O.; Van Doorslaer, E.; Rannan-Eliya, R.; Somanathan, A.; Adihkari, S.; Akkazieva, B. et al. (2008) Who pays for health care in Asia? Health Econs, 27: 460-475.

Onibukun, A.G. (2003). The impact of user fee on health delivery services in Nigeria. Ibadan: Centre for African Settlement Studies and Development (CASSAD), Monograph Series no. 19, Pp 60.

Peters, D.; Yazbeck, A.; Sharmaand, R.; Ramana, G. (2001) Pritchett. L.; Wagstaff, A. Better health systems for India's poor. World Bank.

Reardon, T.; Malton, P.; Delgado, C. (1988) Coping with household level food insecurity in drought-affected area of Burkina Faso. World Development, 16(65).

Russell, S.; Abdella, K. (2002) Too poor to be sick: coping with the costs of illness in East Hararghe, Ethiopia. London: Save the Children.

Russell. S. (1996) Ability to pay for health care: concepts and evidence. Health Policy Plan, 11: 219-237.

Sauerborn, A.; Adams, A.; Hien, M. (1996) Household strategies to cope with the economic costs of illness. Soc Sc Med, 43: 291-301.

Swift, J. (1989) Why are rural people vulnerable to famine? IDS Bull, 20(8).

Taiwo, P.A. and Owumi, B.E. (2014) "Integrating Health Services into Microfinance Operations for Sustainable Poverty Alleviation: The Case of Female Clients in Edo State". Ibadan Journal of the Social Sciences, 12(2): 125-146.

Wagstaff, A.; Van Doorslaer, E. (1993) Catastrophe and impoverishment in paying for health care: with applications to Vietnam 1993-1998. Health Econs, 12: 921-934.

Xu, K.; Evans, D.; Carrin, G.; Aguilar-Rivera, A.M.; Musgrove, P.; Evans, T. (2007) Protecting households from catastrophic health spending. Health Aff, 26: 972-983.

Xu, K.; Evans, D.B.; Kawabata, K.; Zeramdini, R.; Klavus, J.; Murray, C.J. (2003) Household catastrophic health expenditure: a multi country analysis. Lancet, 362: 111-117.

Yu, H.; Wilkes, A. (1998) Coping with the costs of severe illness in rural China. Chinese Health Econs, Chinese, 17: 42-45. 